\title{
Cikkismertetés: Az ingyenes iskolai gyümölcsprogram változtat-e az egészségtelen rágcsálnivalók fogyasztásán?
}

\author{
Article review: Does exposure to a free school fruit programme modify the \\ unhealthy snacks consumption?
}

Ismertető: $\quad$ Devosa Iván $\square$
Neumann János Egyetem Pedagógusképző Kar, Egészségtudományi és
Egészégfejlesztési Kutatócsoport

Ismertetett cikk: Hovdenak IM, Stea TH, Twisk J et al. Tracking of fruit, vegetables and unhealthy snacks consumption from childhood to adulthood (15year period): does exposure to a free school fruit programme modify the observed tracking? Int J Behav Nutr Phys Act. 2019 Feb 15;16(1):22 doi: 10.1186/s12966-019-0783-8

Beküldve: $\quad$ 2019. 03. 07.

doi: $\quad$ 10.24365/ef.v60i2.437

Kulcsszavak: zöldség- és gyümölcsfogyasztás; egészségtelen rágcsálnivalók; étrendszokások; gyermekek; iskolai gyümölcsprogram

Keywords: fruit and vegetables consumption; unhealthy snacks; dietary habits; children; school fruit scheme

\section{HÁTTÉR}

Számos korábbi, empirikus tanulmány eredményéből ismert, hogy már korai életkorban fontos a gyümölcs- és zöldségfogyasztás megkedveltetése, hiszen a gyermekkori táplálkozási szokások felnőttkorban is megmaradnak. A szerzők megjegyzik, hogy a korábbi empirikus vizsgálatoknak számos korlátja van: pl. alacsony vizsgálati minta, néhány ismételt mérés és/vagy rövid megfigyelési időszak. Ezenkívül a szerzők tudomása szerint egyetlen tanulmány sem bizonyította még, hogy a gyermekkorban kialakult étkezési szokások mérése befolyásolja-e a későbbiekben az étkezési szokások nyomon követhetőségének a lehetőségét. A tanulmány egyik fő célkitűzése éppen ezért a gyümölcsés zöldségfogyasztás, valamint az egészségtelen nassolás nyomon követésének nagy mintaszámú, több mint 15 éven át tartó, többszörös felmérésekkel végzett vizsgálata volt. Továbbá a kutatók azt is vizsgálták, hogy az iskolai környezetben egy tanéven belül változik-e a gyümölcs- és zöldségfogyasztás gyakorisága.

\section{MÓDSZER}

A „Fruit and Vegetables Make the Marks” címú kutatás 38, véletlenszerüen kiválasztott iskolával dolgozott Norvégiában. Az iskolák közül 9 kapott ingyenes gyümölcsöt vagy zöldséget a 2001/2002es tanévben, 29 iskola diákjai pedig a kontrollcsoportot alkották. A kiindulási minta 1950 gyermekből állt (984 lány, 585 fiú), a résztvevők 16-92\%-a további 5 nyomonkövetési felmérésben (20022016) vett részt. A gyümölcs- és zöldségfogyasztást, 
illetve az egészségtelen harapnivalók fogyasztását élelmiszerfogyasztási gyakoriság kérdőívvel (Food Frequency Questionnaire), illetve 24 órás táplálkozási kérdőívvel mérték. A teljes nyomonkövetési együtthatók becsléséhez vegyes modelleket alkalmaztak, csakúgy, mint annak értékelésére, hogy a kutatás módosította-e a nyomon követés eredményét. Azt, hogy maga a kutatás módosította-e a nyomon követés eredményét, két időszakban vizsgálták: a kiindulástól az első nyomonkövetéses vizsgálat során (a vizsgálat ideje alatt), illetve a második nyomonkövetéses vizsgálat során (a kutatás befejezése után).

\section{EREDMÉNYEK}

A teljes nyomonkövetési együttható 0,33 volt a gyümölcsök, 0,36 pedig a zöldségek esetében. Ez az egészségtelen harapnivalók esetében nemek szerint különbözött: 0,46 volt a fiúk és 0,39 a lányok esetében $(p=0,065)$. A legtöbb elemzés nem mutatott szignifikáns különbséget a kísérleti csoport és a kontrollcsoport között, azonban az alacsony iskolázottságú szülók gyermekei körében csökkent az egészségtelen rágcsálnivalók fogyasztásának aránya. A nyomon követés során viszont az egészségtelen harapnivalók esetében a teljes nyomonkövetési együtthatók eltérőek voltak: 0,46, illetve $0,38 \quad(p=0,036)$. A második nyomonkövetéses vizsgálatnál 0,35 és $0,48(p=0,036)$ voltak az értékek a zöldségeknél a kísérleti csoport és kontrollcsoport között.

\section{KÖVETKEZTETÉSEK}

Eredmények azt mutatják, hogy a gyümölcs- és zöldségfogyasztás, valamint az egészségtelen harapnivalók fogyasztása alacsony vagy közepes mértékű gyermekkortól felnőttkorig. Kevés bizonyítékot találtak arra vonatkozóan, hogy az ingyenesen hozzáférhető gyümölcs vagy zöldség módosította volna azok, illetve az egészségtelen harapnivalók fogyasztását. További kutatásokra van szükség ahhoz, hogy bizonyosságot nyerjünk, hogyan befolyásolható a gyümölcsök, zöldségek, valamint az egészségtelen harapnivalók fogyasztása a népesség egészségének javitása érdekében.

\section{TANULSÁGOK A HAZAI SZAKEMBEREK SZÁMÁRA}

A kutatás a magyar szakemberek számára is fontos információkkal bír, ugyanis hazánkban jelenleg is folyik az iskolagyümölcs-program, illetve a menzai étkeztetés és az iskolabüfé kínálatának egészségesebbé tétele. A tanulmány arra is rámutat, hogy aktív szülói részvétel nélkül ezek a változások a gyermekek étrendjében nem lesznek tartósak. Mindezek miatt javaslom, hogy az iskolai egészségfejlesztő programokba próbálják meg a szülőket is bevonni, ezzel is növelve a programok hatékonyságát.

\section{KÖSZÖNETNYILVÁNÍTÁS}

Köszönettel tartozunk a publikálás támogatásáért, amely az EFOP-3.6.1-16-2016-00006 „A kutatási potenciál fejlesztése és bővítése a Neumann János Egyetemen” pályázat keretében valósult meg. A projekt a Magyar Állam és az Európai Unió támogatásával, az Európai Szociális Alap társfinanszírozásával, a Széchenyi 2020 program keretében valósul meg. 